of the family until 1913, long after his older brothers had come to attend chiefly to the New York end of their expanding silver and copper interests. $\mathrm{He}$ also served during that time as director of the Guggenheim Exploration Co., American Smelter Securities Co., American Export Co., and the American Smelting and Refining Co.

While he long represented the family interests in the field, he always participated in general administration. The brothers met frequently to discuss their problems and to decide upon policy, and each was allotted his specific tasks in the management of their business. As the youngest of the four brothers active in silver and copper interests, Simon had to take over more and more of general administrative responsibilities as his brothers retired. In 1919 he followed his brother Daniel as president of the American Smelting and Refining Co., which position he held until his death.

Thus Simon Guggenheim stood at the forefront in American and, indeed, world mining in its period of rapid growth. He early participated in promoting exploration and mining development from Utah to Chile and later on other continents. He helped materially to develop the use of low-grade ores and to make possible great advances in metallurgy. And he helped to build a great international mining and smelting organization, an integrated concern which under his administration became the largest of its kind in the world.

\title{
Acquisition of Material from the Poor Publishing Company
}

The old adage about an "ill wind" should have a qualifying phrase, at least as far as library acquisition is concerned. In order that libraries or historical institutions may benefit from others' adversities, it is essential that they have a friend in the neighborhood of the cyclone or other trouble-making wind. The Baker Library of the Harvard Graduate School of Business Administration was fortunate in having such a friend in Mr. Paul D. Babson.

The radical change in stock- and bond-market activities which 
has derived from the depression and the subsequent regulatory legislation was undoubtedly the primary cause of the recent amalgamation of two important companies which, for a number of years, had competed in the purveying of financial information. These were the Poor Publishing Company which had its headquarters at Wellesley Hills, Massachusetts, and the Standard Statistics Company with its head office in New York City. Covering substantially the same ground and selling their services to similar financial institutions, these two companies had largely duplicate files. The amalgamation decided to carry on future business in New York City; and, after a comparison of the two collections and the transference to New York of some small quantity of material from the Poor assembly, it was decided that the remaining great bulk of the Poor library should be disposed of. Mr. Paul D. Babson, the president of the Poor Publishing Company and now the president of the combined corporation, offered to the Business School the whole mass of material, which was accepted readily despite the problem of absorbing so many thousand items.

The material, thus moved from Wellesley Hills to Soldiers Field, consisted literally of thousands of manila folders, each containing current and recent reports, brokers' circulars, mortgages, and other data concerning thousands of American and foreign corporations in the various fields of banking, transportation, insurance, manufacture, and merchandising. In addition, there was a ton or more of material from the "morgue" of the Poor enterprise which, as far as the Business School Library was concerned, was welcomed as eagerly as that contained in the thousands of folders. This "morgue" collection consisted of historical items, non-recent and non-current, which, for an enterprise such as Poor's. had ceased to be of immediate interest but which. for those interested in the study of business history, is of continuing significance.

This large acquisition. running literally to hundreds of thousands of individual pieces, is being absorbed into the Corporation Records Division of the Business School Library as rapidly as can be done by the staff, with the assistance of scholarship students. It will enlarge and enrich the already substantial collection of material relating to the financial careers of American corporations.

Arthur H. Cole,

Harvard University. 